\title{
Analysis on Implementation Strategy of Large-scale Class Teaching for College English under Teaching Paradigm Reform Mode
}

\author{
Min Liu \\ School of Foreign Languages, Shangqiu Normal University, Shangqiu, Henan, 476000, China
}

Keywords: teaching paradigm reform; College English; Large-scale class teaching; implementation strategy

\begin{abstract}
In large-scale class teaching process of college English, the teacher should keep improving students' practical application ability due to strong applicability of English knowledge. In this way, the entire quality of talent training can be guaranteed. Especially under the educational mode of teaching paradigm reform, traditional large-scale class teaching for English has certain problems and defects. To effectively improve course teaching quality and cultivate excellent applied English talents, large-scale class teaching reform for college English has been imperative. Based on deep analysis of large-scale class teaching characteristics of college English, the teaching implementation strategy under teaching paradigm reform mode is expounded in detail.
\end{abstract}

\section{Introduction}

Under current education form, the fundamental change has happened to the demand situation for talents, especially for English talents. Influenced by traditional education concept, college English teaching is still in the traditional form. The attention to cultivation of students' practical English application ability is far from enough, which to a large extent affects practical effect of English course teaching and becomes a main obstacle hindering talent training. This problem can be fundamentally solved inly through conducting fruitful teaching reform for college English teaching and promoting applicability and effectiveness of talent training. Therefore, deep analysis of effective countermeasures to implement large-scale class teaching for English under teaching paradigm reform mode is of great theoretical and practical significance for promoting talent training and college English teaching quality.

\section{Problems of Large-scale Class Teaching for English under Teaching Paradigm Reform Mode}

\subsection{The lack of scientific and reasonable planning and arrangement in teaching content}

For students, the scientific and reasonable teaching content is very critical for students, which directly concerns students' acceptance and understanding degree ${ }^{[1]}$. For the same knowledge content, if the teacher plans it scientifically and reasonably before class, and implements teaching activity in strict accordance with the plan, students will accept and understand he knowledge fast. On the contrary, students' learning will be affected. In current large-scale class teaching for college English, unscientific teaching content exists generally. Some teachers blindly infuse theoretical knowledge in order to pursue the entire teaching quality and teaching effect. Besides, they make the teaching program according to their own wish, and purely consider students' comprehensive quality can improve as long as the teaching standards increase. They ignore students' learning and growth features in teaching practice. As a result, students' learning does not conform to their intelligence development. In this way, the expected effect of improving teaching quality cannot be reached. On the contrary, larger adverse effects will be caused for students' future study. 


\subsection{The formalized application of teaching methods, lacking practical significance}

The new round of course reform has been conducted for a period, and certain achievements have been gained. As the course reform proceeds, some novel teaching modes also spring up gradually, many of which are very effective, change traditional teaching form and teaching concept and greatly promote the entire teaching quality. However, some problems still exist ${ }^{[2]}$. Affected by inherent teaching concept, some teachers neither well accept the brand-new teaching modes nor well understand them. In practical application process, these teachers are influenced by course reform trend and pursue teachings form innovation. They just apply the teaching form formalistically. Some teachers even excessively pursue teaching form and ignore the initial purpose of teaching. Judging by appearance, the teachers well apply the new teaching methods, but the expected effect of teaching methods is not well exerted. Sometimes, lots of class time is wasted due to the pursuit of teaching form, which affects teaching quality. As a result, the loss outweighs the gain.

\subsection{The lack of knowledge summarization and feedback process}

In accordance with the normal learning rules, students need to summarize and feed back corresponding knowledge points after they learn them so as to better help them understand and master new knowledge as well as own practical application ability. New curriculum standard also deems students' practical application ability as the main cultivation objective. But judging from large-scale class teaching for college English, there is no new knowledge training and feedback process. To pursue teachings progress, some teachers often neglect knowledge training and application. After students learn new knowledge, teachers should carry out targeted training in time and examine students' knowledge mastery degree from different perspectives ${ }^{[3]}$. In the practice process, teachers can find the weak knowledge points and mistakes, and thus give targeted explanations to facilitate their better understanding and mastery. But it is a pity that, there is generally lack of training and feedback process in large-scale class teaching for college English. Students master new knowledge differently, which affects the entire teaching quality.

\subsection{Vague teaching objective and classroom teaching}

Since teacher's quality differs, their teaching methods also differ a lot. Thus, large differences will also appear in the teaching process. But no matter which teaching mode is applied, the main teaching objective is same. And, the aching means serve for promoting teaching quality ${ }^{[4]}$. In large-scale class teaching for college English under teaching paradigm reform mode, teachers should have explicit teaching objectives so that they will be more targeted and oriented in teaching design and planning process and lay a good foundation for effective implementation of classroom teaching. But in large-scale class teaching for college English, some teachers lack explicit teaching objectives, and the teaching process is also at will. There is short of scientific and reasonable teaching planning. These affect the entire quality of large-scale class teaching for college English.

\section{Basic Problems to be noticed in Large-scale Class Teaching for College English under Teaching Paradigm Reform Mode}

\subsection{Pay attention to English knowledge systematicness and help students establish complete knowledge hierarchy}

In teaching practice, knowledge has strong systematicness. Thus, learning process also should follow the principle of systematicness to avoid separation of knowledge integrality and disturbance of comprehension. Under current network development background, fragmented information knowledge is inundated with the whole network. Thus, some teachers also implement fragmented teaching in large-scale class teaching for college English under teaching paradigm reform mode. They do not focus on knowledge consistency. Students learn in a one-sided manner, and lack systematic understanding. Besides, students cannot associate relevant knowledge in practical application process, which brings about large adverse effect on learning effect ${ }^{[5]}$. To effectively 
promote the entire quality of large-scale class teaching for college English, and give play to the practical role of teaching paradigm reform, knowledge systematicness should be valued. In addition, it is required to make reasonable planning in the teaching reform process, help students establish complete knowledge hierarchy, clarify the knowledge, take the course teaching objective as the principal line, find out the key connection point, make course reform deep in each teaching link, grasp knowledge systematicness and integrality and effectively improve teaching quality.

\subsection{Highlight students' subject status in teaching paradigm reform}

In the learning process, students are not passive knowledge receivers, but should continuously enrich and improve new knowledge and construct knowledge framework according to existing knowledge system so as to enhance their comprehensive quality. All these should be actively completed by students. But under traditional education concept, students' initiative is not furthest exerted. Their subject status in classroom is totally replaced by the teacher. Students learn in accordance with teacher's thought, and lack the process of active thinking ${ }^{[6]}$. Meanwhile, the restraints of various rules and regulations also restrict students in the existing space, and their creativity and learning thinking cannot be well exerted, thus affecting the entire teaching quality. Therefore, in large-scale class teaching for college English under teaching paradigm reform mode, teachers should fully focus on students' subject status, actively innovate teaching form, give play to teachers' guidance function, improve students' subjective initiative, guide students' active thinking, change the teaching defect of passive acceptance of knowledge, and make students develop independent learning habit, enhance learning confidence and lay a solid foundation for future deep learning.

\section{Effective Strategies on Large-scale Class Teaching for College English under Teaching Paradigm Reform Mode}

\subsection{To give play to the advantages of teaching paradigm reform and effectively promote teaching quality}

Under the background of course reform, the fundamental purpose of teaching method application is to facilitate students to better learn relevant knowledge and improve teaching quality. The simple and formalistic application cannot reach the expected purpose. Thus, in large-scale class teaching for college English, the advantages of teaching paradigm reform should be fully exerted. First of all, it is required to pay attention to improvement of teachers' professional accomplishment, update teachers' traditional education concept in time, deeply cognize teaching paradigm reform and firmly grasp the essence of teaching paradigm reform mode. This is the first step of teaching paradigm reform mode ${ }^{[7]}$. The main reason why teaching reform failed to give play to tis role in the previous teaching practice is that teachers did not well understand the teaching reform and only applied it formalisticlly, thus largely reducing the application effect. Secondly, teachers should perfectly combine teaching paradigm reform mode and large-scale class teaching for college English. Due to the different subject nature, the features of English should be deeply studied in teaching method application process. Then, individualized integration of the features and teaching paradigm reform mode should be done to achieve the practical effect of promoting teaching quality.

\subsection{To improve teaching evaluation mode and lay a solid foundation for effective implementation of large-scale class teaching}

Teaching evaluation includes student assessment and teacher evaluation, and intensively reflects teachers' teaching and students' learning level. The previous teaching evaluation has certain problems. It pays attention to teachers' teaching progress and teaching result, and excessively focuses on students' test results. This is obviously unscientific, and also directly affects teaching quality of large-scale class teaching for college English. Under teaching paradigm reform mode, the traditional teaching mode should be adjusted again. For teachers, they cannot regard teaching progress as the 
evaluation index. Teacher's teaching quality, professional ethics, application of teaching methods and teaching effect should be brought in the evaluation system to comprehensively examine teachers' teaching. For students, the proportion of test score should decrease. Classroom performance, comprehensive ability promotion and learning attitude should be included in the examination scope to evaluate students' learning more deeply. In this way, the teaching mode can be measured more objectively, and favorable basic conditions can be provided for teacher's innovative teaching. Meanwhile, the teaching defect of blindly pursuing test score can be avoided, and teaching quality can improve.

\subsection{To establish explicit college English teaching objective}

In current large-scale class teaching for university English, unclear teaching objective is one of main problems influencing teaching quality improvement. To solve this problem fundamentally, teachers should first establish the explicit teaching objective before teaching. To be specific, teachers should deeply understand students' learning and knowledge mastery degree under the guidance of English teaching program and the precondition of obeying teaching standards, and then combine course standards to formulate the scientific and reasonable teaching objective ${ }^{[8]}$. Teachers should abandon the wrong teaching method of arranging the period at will, help students establish complete English knowledge system through scientific teaching design, explain the new knowledge points, let students review the learned knowledge, help them form a benign teaching circle and gradually improve their comprehensive quality, and promote continuous improvement of large-scale class teaching for college English. For the problems in learning process, teachers should treat them differently, explain individual problems and enhance the general problems. This can help students eliminate the obstacles in learning process, improve their comprehensive quality and enhance teaching pertinence and effectiveness.

\section{Conclusion}

In conclusion, certain problems exist in large-scale class teaching for college English under teaching paradigm reform mode. These problems are also the main obstacles influencing teaching quality improvement. So in teaching practice, large-scale class teaching form for college English should actively innovate and improve. Meanwhile, teaching paradigm reform mode should be applied to promote teaching pertinence and effectiveness, facilitate students to better accept and understand the learned knowledge and promote continuous improvement of large-scale class teaching quality.

\section{References}

[1] Wang Junxia, Chen Huijun, Culture Interaction Paradigm: Research on College English Teaching Reform under Cross-cultural Perspective, Heilongjiang Researches on Higher Education, 2018(2): 148-151.

[2] Qiu Yuyi, College English Learning Strategy Based on Communicative Teaching Platform, Journal of Guangxi Normal University (Philosophy and Social Sciences Edition), 2015(1):174-178.

[3] Wang Tianjian, Multivariate generalizability analysis based on English teacher evaluation by college students - case study of teachers of a college involving in teaching paradigm reform experiment, Journal of Wenshan University, 2017(6):90-93.

[4] Wang Jin, Identity Issues of College English Teachers Confronting the "Post-College English Test Era", Journal of Yancheng Institute of Technology (Social Science Edition), 2016(4):82-86.

[5] Zhu Luhui, Zhan Suxian, Students'Voices of Effective College English Language Instruction in the Context of Educational Reform, Overseas English (I), 2015(11):27-29.

[6] Meng Fanxu, China's College English Education Reform Paradigm under the Background of the Fourth Industrial Revolution, Journal of Liaoning Institute of Science and Technology, 
2017(6):47-50.

[7] Liu Yujie, Fan Min, Research on the Influence of the Reform of College Entrance Examination in English on College English and Its Countermeasures, Journal of Jilin Teachers Institute of Engineering and Technology, 2015(3):32-33.

[8] Wang Jin, Lan Huan, The "Entertainment” Problem and Reforming Strategy in Optional College English Courses, Journal of Changchun Institute of Technology (Social Sciences Edition), 2015(2):140-142. 